Research Article

\title{
Pharmacognostical, Phytochemical Screening, Formulation and Evaluation of Nanophytosomes of Aqueous Extracts of Trigonella foenum graecum., (Fabaceae)
}

\author{
Anitha Pramanayakam*, Arjunkumar Panneerselvam ${ }^{1}$ \\ *Department of Pharmacognosy, Arulmigu Kalasalingam College of Pharmacy, Krishnankoil- 626126, Srivilliputtur (via), Virudhunagar \\ (Dt), Tamilnadu, India. \\ ${ }^{1}$ Department of Pharmaceutics, Arulmigu Kalasalingam College of Pharmacy, Krishnankoil- 626126, Srivilliputtur (via), Virudhunagar \\ (Dt), Tamilnadu, India. \\ *Corresponding author's E-mail: anithasvgm6@gmail.com
}

Received: 18-06-2021; Revised: 23-08-2021; Accepted: 29-08-2021; Published on: 15-09-2021. ABSTRACT

Traditional approach is the one of the emerging field of biomedical sciences. In this research work, we have evaluated the traditional approaches of the ancient healer plant $T$. foenum graecum belonging to fabaceae family. The leaves of $T$. Foenum graecum was subjected to extraction process, phytochemical analysis, preparation of phytosome and evaluation of its characterization. The scientific data shows that, leave extracts contain flavonoids, alkaloids and glycosides etc., Nanophytosome was prepared by thin layer lipid hydration method. The preparation was evaluated for DSC, FTIR, SEM, TEM and particle size analysis. Recently, Nanophytosome methodology has been fruitfully applied over several well-known natural drugs such as ginseng, green tea hawthorn, olive oil and grape seed etc. Indeed, phytosome are superior to conventional drug delivery systems in terms of the pharmacodynamic and pharmacokinetic properties. This research, we discusses the various aspects, components, methods of preparation of phytosome and their marketed formulations, therapeutic applications along with the recent research work reported on this technology.

Keywords: Nanophytosome, T. foenum graecum, herbal extract, phytosome.

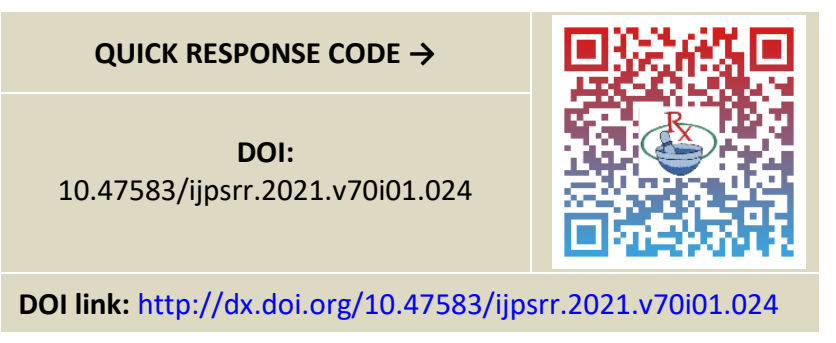

\section{INTRODUCTION}

E: ver since the birth of mankind there has been a relationship between disease and plants. There is no record that people in prehistoric times used synthetic medicines for their ailments. But they tried to make use of the things, which were easily available, i.e, the plants and animals. Plants have been used for medicinal purpose long before and recorded in the history. The term 'Phyto' means plant while 'Some' means cell-like. Phytosome is vesicular drug delivery system in which phytoconstituents of herb extract surround and bound by lipid. The Phytosomes process produces a little cell because of that the valuable components of the herbal extract are protected from destruction by digestive secretions and gut bacteria. Phytosomes are better able to transition from a hydrophilic environment into the lipidfriendly environment of the enterocyte cell membrane and from there into the cell finally reaching the blood. Phytosomes proves to be of significantly greater clinical benefit. ${ }^{1,2}$

Trigonella foenum graecum Linn., belonging to the family fabeaceae and sub family papilionaecae is cultivated throughout the country. It is nearly smooth erect annual plant. It is cultivated in India, Africa, Egypt, Morocco, and occasionally in England. Hulba is native to South Europe and Asia. The plant is widely cultivated in many Parts of India. It has been proven to be an excellent remedy for reducing level of bad Cholesterol levels from our body. It purifies blood and helps in flushing out the harmful toxins. They give strong mucilage, which is emollient and a decoction. Leaves to 1 pint water are used internally in inflamed conditions of the stomach and intestines. Externally it is used as a poultice for abscesses, boils, carbuncles, etc. It can be employed as a substitute for codliver oil in scrofula, rickets, anaemia, debility following infectious diseases. ${ }^{3,4}$

\section{MATERIALS AND METHODS}

\section{Collection Of Plant Material}

The Leaves of the plant $T$. foenum graecum were collected locally authenticated, cleaned and then they are shadow dried for 2 days and they are made into powder for further studies.

\section{Preparation of Extraction}

The leaves were shade dried on the laboratory bench for 10 days. The dry sample was milled and ground into powder. Extraction involves the separation of a bioactive portion of the plant tissues from the inactive components by using selective solvents in standard extraction procedure. The dried coarse powder of leaves of $T$. foenum-graecum was extracted with $500 \mathrm{ml}$ of water by Cold maceration method. After 72 hours, the extract was 
collected by filtration, evaporated to dryness. The collected extract was stored in desiccators at room temperature and used for further pharmacological study.

\section{Macroscopic Characters}

The morphological studies were carried out for different parameters such as shape, size, color, odor and taste and fracture identification of the fenugreek seed. ${ }^{5}$

\section{Microscopic Characters}

The dried seeds of Trigonella foenum graecum were taken and soaked overnight in tertiary butyl alcohol, pieces transfer in ethanol for 2 hours and the sections were stained with phloroglucinol and examined under microscope. ${ }^{6}$

\section{Physicochemical Parameters}

The determination of various physicochemical parameters such as total ash, acid insoluble ash, water soluble ash, water soluble extractive value, alcohol soluble extractive value, swelling index, foaming index, moisture content, ash value, $\mathrm{pH}$ were calculated as per Indian Pharmacopoeia. ${ }^{7}$

\section{Preliminary Phytochemical Screening}

For preliminary Phytochemical screening, $100 \mathrm{~g}$ of powder drug was extracted with Distilled water. The plant extract obtained from successive solvent extraction were then subjected to various qualitative chemical tests to determine the presence of various Phytoconstituent like glycosides, phytosterols, fixed oils and fats, alkaloids, proteins and amino acids, flavonoids, saponins, gums and mucilage etc. ${ }^{8}$

\section{Preparation of Trigonella foenum graecumnano- Phytosomes}

\section{Thin Layer Lipid Hydration Method}

Accurately weighed quantity of phosphotidyl choline and cholesterol were dissolved in $10 \mathrm{ml}$ of chloroform in round bottom flask (RBF) and sonicated for 10 min using bath sonicator. Organic solvent removal is done by Rotary evaporator $\left(45-50^{\circ} \mathrm{C}\right)$. After complete removal of solvent thin layer of phospholipids mixture was formed. This film was hydrated with aqueous extract of $T$. foenum graecum leaves in rotary evaporator $\left(37-40^{\circ} \mathrm{C}\right.$ for 1 hour). After hydration, mixture of lipid and plant extract was sonicated for 20 minutes in presence of ice bath for heat dissipation. Then prepared $T$. foenum graecum Nano-Phytosomes were filled in amber coloured bottle and stored in freezer $\left(2-8{ }^{\circ} \mathrm{C}\right)$ until used. ${ }^{9}$

\section{Evaluation of Trigonella foenum graecum Nano- Phytosomes}

\section{Fourier Transform - Infra Red Spectroscopic Analysis (FT- IR)}

To investigate the interaction of T.foenum-graecum leaves extract and Phospholipids in T. foenum graecum nanophytosome complex, FT-IR spectra were measured. FT-IR spectral data can be taken to determine the structure and chemical stability of $T$. foenum graecum aqueous extract, physical mixture of phosphoditylcholine and cholesterol, nano-phyto $T$. foenum graecum some complex. The spectroscopic evaluation of the formed complex can be confirmed by FT-IR simply by comparing the spectrum of the complex and the individual components and that of the mechanical mixtures. Samples were mixed with dry crystalline $\mathrm{KBr}$ in a ratio of $1: 100$ and pellets were prepared. The mixture was grounded or triturated into fine powder using an agate mortar before compressing into $\mathrm{KBr}$ disc. Each $\mathrm{KBr}$ disc was scanned at $4 \mathrm{~mm} / \mathrm{s}$ at a resolution of 2. FT-IR can also be considered as a valuable tool in confirming the stability of the nano-phytosomal complex. FT-IR spectra were obtained using a FT-IR spectrometer. Spectral scanning can be done in the range of $4000-400 \mathrm{~cm}^{-}$ 1.10

\section{Differential Scanning Calorimetry (DSC) Analysis}

Thermodynamical techniques are applied for determining the thermal stress of medicinal compounds of the excipients as well as their interactions during the formulation process. The thermal analysis of the $T$. foenum graecum leaves extract, physical mixture of phospholipidsand cholesterol, $T$. foenum graecum nanophytosome complex were placed in the aluminium crimp cell and heated at $10{ }^{\circ} \mathrm{C} / \mathrm{min}$ from 0 to $400^{\circ} \mathrm{C}$ in the atmosphere of nitrogen (TA Instruments, USA, model DSC Q10 V24.4 Build 116). Peak transition onset temperatures were recorded by means of an analyzer. ${ }^{11}$

\section{Particle Size and Zeta Potential}

The particle size and Zeta potential of $T$. foenum graecum Nano-phytosome were assayed by dynamic light scattering (DLS) using a Malvern Zetasizer Nano-ZS (Malvern Instruments, Worcestershire, UK). Scattered light was detected at a $173^{\circ}$ angle. All measurements were performed in the standard suitable conditions to validate the results of sample dilution and the constant temperature of $25^{\circ} \mathrm{C}$. Furthermore, the apparatus we used systematically and automatically adapts to the sample, the intensity of the laser as well as the attenuator. Therefore, the reproducibility of the experimental measurement conditions is ensured. ${ }^{12}$

\section{Scanning Electron Microscope (SEM) analysis}

Scanning electron microscopy has been used to determine particle size distribution and surface morphology of the $T$. foenum graecum nano-phytosome complexes. Samples were studied using JEOL JSM-6360 Scanning microscope (Japan). Approximately $5 \mu \mathrm{L}$ of the nano-phytosomal solution were suspended in absolute alcohol and transformed to a cover slip, which in turn was mounted on a specimen tab. The samples were allowed to dry at room temperature. Then the particle size of the formulation was viewed and photographed using Scanning Electron Microscope (Sigma, Carl Zeiss). Digital images of nanophytosome complex of $T$. foenum graecum were taken by random scanning of the stub at 1000, 5000, 10000 and $30000 \mathrm{X}$ magnifications. ${ }^{13}$ 


\section{Transmission Electron Microscope (TEM) Analysis}

Vesicles morphology of $T$. foenum graecum nanophytosome was observed visually Transmission Electron Microscopy (TEM; H-7500, Hitachi Scientific Instruments Ltd., Japan)). A total volume of $10 \mathrm{ml} T$. foenum graecum nano-phytosome was dispersed before the analysis. The mixture was then stirred and a drop of the sample was placed on a 400-mesh copper grid coated with carbon. After 20mins, the grid was tapped with filter paper to remove surface water and stained using a solution of phosphotungstic acid $(2 \% \mathrm{w} / \mathrm{v})$ for 20 mins. Then the stained sample was dried in air and the morphology was observed. ${ }^{14,15}$

\section{X-Ray Diffractometer (XRD) Analysis}

X-Ray diffractometer (XRD) is a unique method in determination of crystallinity of a compound and when properly interpreted, by comparison with drug XRD pattern before formulation, allows the identification of the drug crystalline changes. XRD was done on pure extract, physical mixtures of phosphotidyl choline and cholesterol, $T$. foenum graecum nano-phytosome complex to see the crystallinity in the substance. Sample was scanned in the angular range of 50 - 800 in a PHILIPS X-Pert Pro X-Ray Diffractometer. Dried powder sample was kept in sample holder $(20 \mathrm{~mm} \times 15 \mathrm{~mm} \times 2 \mathrm{~mm}$ ) which was fitted into the instrument and X-ray was passed through the sample. ${ }^{16}$

\section{RESULTS AND DISCUSSION}

\section{Macroscopic Leaves of Trigonella foenum graecum}

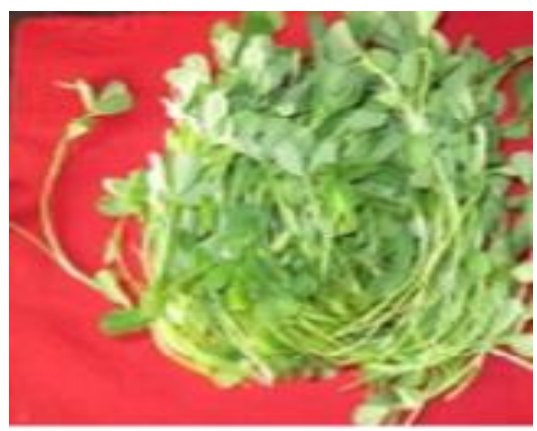

Figure 1: Aerial parts T. foenum graecum

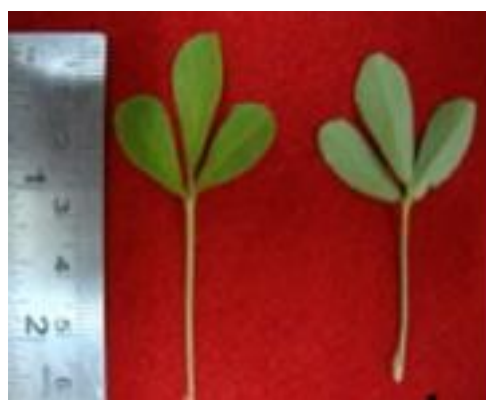

Figure 2: leaves of $T$. foenum graecum

Colour: Yellowish green

Taste: Bitter

Odour: Agreeable

Shape: Ovate
Margin: Crenate

Apex: Obtuse

Size: $3.0-.0 \mathrm{~mm}$ in length, $2.8-4.0 \mathrm{~mm}$ in width

\section{Microsopic Analysis}

Leaves contains upper and lower epidermal cells with wavy anticlinal walls, striated cuticle and anomocytic stomata, more frequent on the lower epidermis; trichomas, more abundant on lower epidermis of two types; covering trichomas, uniserate; glandular trichomas, slightly sunken, composed of a short, biseriate two or four-celled stalk and a biseriate head of four cells, around which the cuticle forms a bladder like covering. Transverse section of seed coat consists of an outer palisade layer. Parenchymatous layer is 1-2 cells thick followed by 2-3 layers of elongated cells of parenchyma. The aleuronic grains are oval to round in shape.

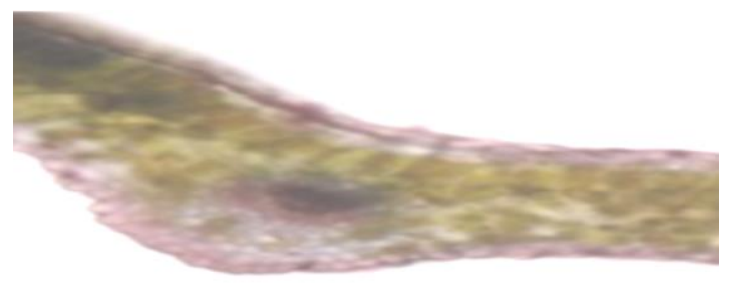

Figure 3: T.S of T. foenum graecum

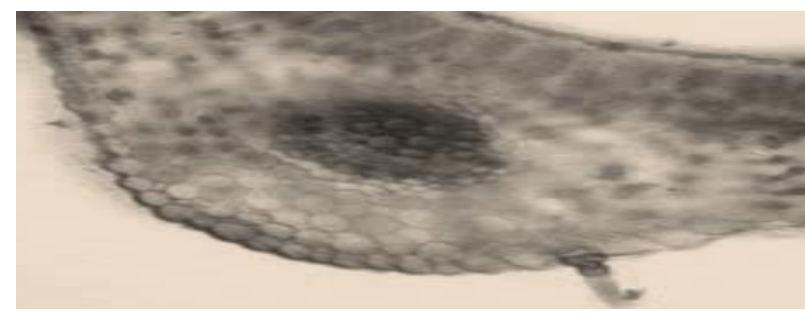

Figure 4: T.S of midrib of T.foenum graecum

\section{Preparation of Extraction}

$T$. foenum graecum plant was extract by using aqueous solvent by cold maceration method. After extraction the decant subject evaporation and hot plate by rotator evaporator, until it get conc. macerate kept in desiccators for complete removal of moisture from the content The products were stored at $-80{ }^{\circ} \mathrm{C}$ for further use. The percentage yield of extract of $T$. foenum graecum was found to be $14 \% \mathrm{w} / \mathrm{w}$.

\section{Physicochemical Evaluation}

The present work is helpful in determining the quality and purity of a crude drug. In this study the parameters used for the evaluation of $T$. foenum-graecum were moisture content, ash values (total ash, water soluble and acid insoluble ash). On incineration, drugs leave an ash which consists of carbonates, phosphates and silicates of sodium, potassium, calcium and magnesium. The determination of ash value is useful for detecting exhausted drugs, lowgrade products and excess of sandy matter which is especially applicable to powdered drugs. 
Table 1: Analytical parameters of Trigonella fonum graecum

\begin{tabular}{|c|c|c|}
\hline S. No & Parameters & Values* expressed as \% \\
\hline $\mathbf{1 .}$ & Moisture content & $4.66 \pm 0.46$ \\
\hline $\mathbf{2 .}$ & Ash values \\
\hline & Total ash & $6.6 \pm 0.25$ \\
\hline & Acid insoluble ash & $1.2 \pm 0.17$ \\
\hline & Water soluble ash & $2.1 \pm 0.40$ \\
\hline
\end{tabular}

\section{Preliminary Phytochemical Studies}

Phytochemical analysis was performed on the aqueous extracts of $T$. foenum-graecum. Aqueous extract contains carbohydrates, proteins and aminoacids, glycosides, alkaloids, flavonoids, phenolic compounds, phytosterols and tannins.

Table 2: Phyto-constituents of Trigonella fonum graecum

\section{S.NO TEST \\ TESTS FOR CARBOHYDRATES \\ a) Molisch's test \\ 1. \\ b) Fehling's test \\ c) Barfoed's test \\ d) Benedict's test}

RESULTS

TESTS FOR ALKALOIDS
a) Mayer's test

2.

b) Dragendroff's test

c) Wagner's test

d) Hager's test

\section{TEST FOR PHENOLIC COMPOUNDS AND}

3. TANNINS

a) Braemer's test

4. TEST FOR TERPENOIDS

5. TEST FOR FLAVONOIDS

a) Shinoda test

\section{TEST FOR SAPONINS}

6.

a) Foam test/ Frothing test

7. TEST FOR VOLATILE OILS TEST FOR GLYCOSIDES

8.

a) Legal's Test

b) Borntrager's Test

TEST FOR PHYTOSTEROLS

9.
a) Libermann-Burchard test
b) Salkowski reactions

$(+)$ indicates positive reaction $(-)$ indicates negative reaction

\section{Evaluation of Trigonella Foenum Graecum Nano- Phytosomes}

Fourier Transform Infra-Red Spectroscopic analysis(FT-

IR)

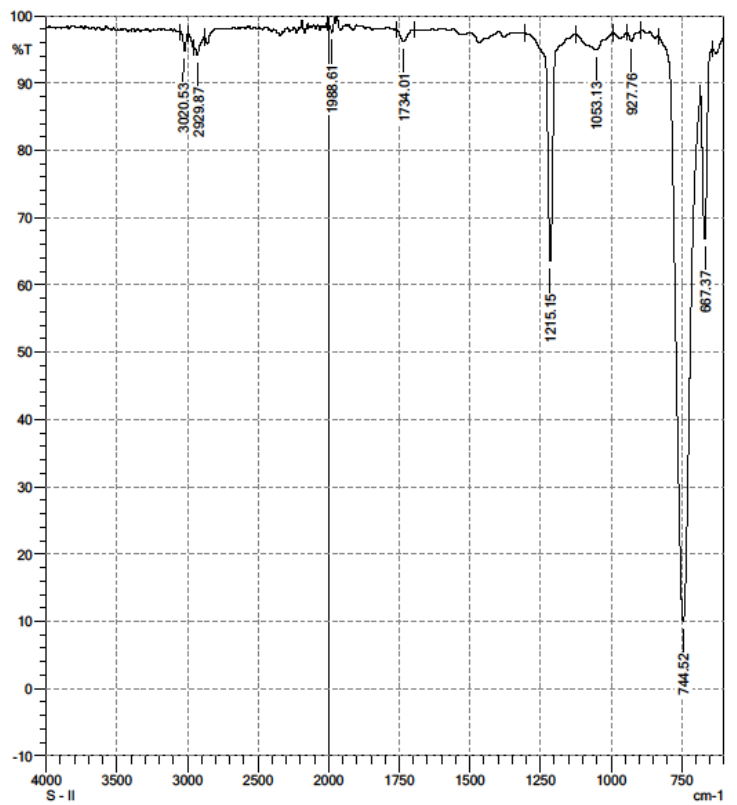

Figure 5: S-I represent FT-IR spectra of Trigonella foenumgraecum extract

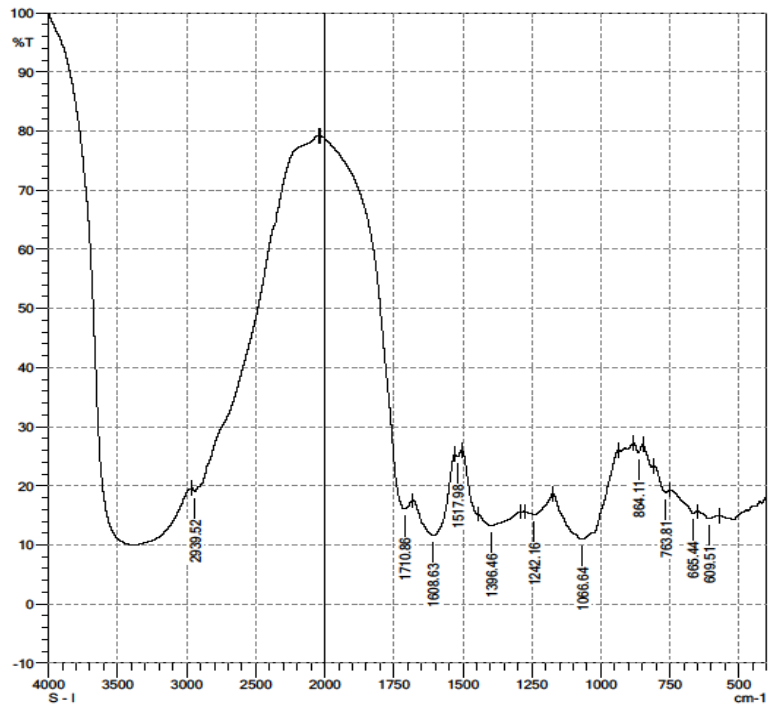

Figure 6: S-II FT-IR spectra of Physical mixture of phospholipids and cholesterol 


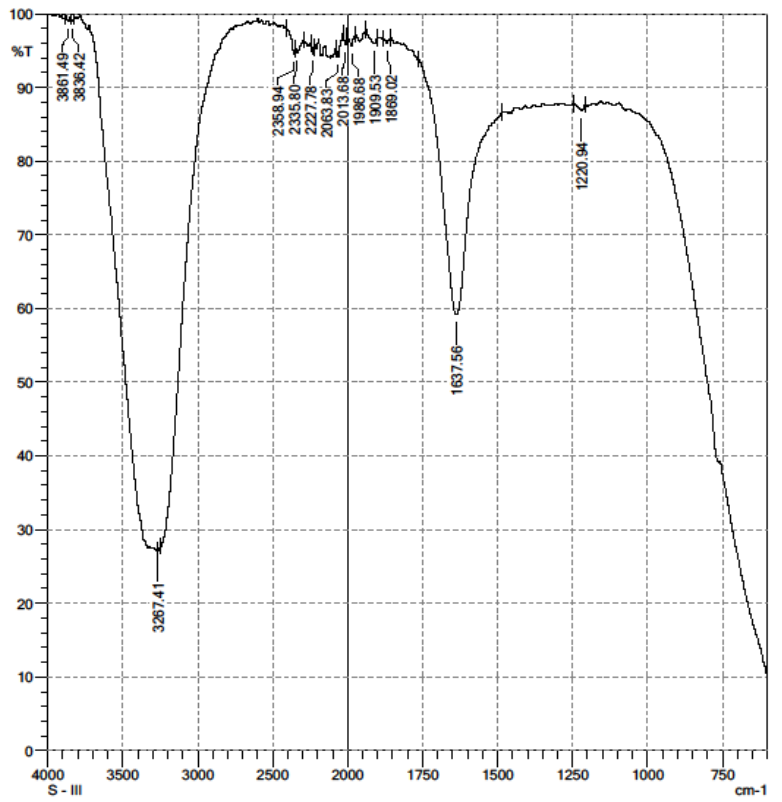

Figure 7: S-III FT-IR Trigonella foenum-graecum nanophytosome

Spectroscopic analysis was used in order to identify and diagnose of complex formation between phospholipid and Trigonella foenum-graecum extract. In FT-IR spectroscopy, functional groups and their numbers were identified from the frequency of radiation that absorbs infrared spectra which showed the main chemical groups in extract and PC as well as the formation of new interactions between them in the nano-phytosomes preparation process (Table 3). The FT-IR spectroscopy of $T$. foenum-graecum leaf extract (S-I), mixture of Cholesterol and phospholipids(S II), T. foenum-graecum nano-phytosome (S-III) are shown figure $9,10,11$. $T$. foenum-graecum leaf extract (S-I) shows that the characteristic $\mathrm{C}-\mathrm{H}$ peak at $2939.52 \mathrm{~cm}^{-1}, \mathrm{C}=\mathrm{O}$ peak at $1710.86 \mathrm{~cm}^{-1}$, C-C peak at $1608.63 \mathrm{~cm}^{-1}$, C-C peak at $1517.98 \mathrm{~cm}^{-1}, \mathrm{C}-\mathrm{H}$ peak at $1396.46 \mathrm{~cm}^{-1}, \mathrm{C}-\mathrm{N}$ peak at $1242.16 \mathrm{~cm}^{-1}, \mathrm{C}-\mathrm{N}$ peak at $1066.64 \mathrm{~cm}^{-1}$. T. foenumgraecum nano-phytosomes (S-III) shows that the characteristic peak at O-H peak at $3861.49 \mathrm{~cm}^{-1}, \mathrm{O}-\mathrm{H}$ peak at $3836.42 \mathrm{~cm}^{-1} 1, \mathrm{~N}-\mathrm{H}$ peak at $3267.41 \mathrm{~cm}^{-1}, \mathrm{C} \equiv \mathrm{N}$ peak at $2358.94 \mathrm{~cm}^{-1}, \mathrm{C} \equiv \mathrm{N}$ peak at $2335.80 \mathrm{~cm}^{-1}, \mathrm{C} \equiv \mathrm{N}$ peak at $2227.78 \mathrm{~cm}^{-1}, \quad \mathrm{C}=\mathrm{C}$ peak at $2013.68 \mathrm{~cm}^{-1}, \mathrm{C}=\mathrm{C}$ peak at $1986.68 \mathrm{~cm}^{-1}, \mathrm{C}=\mathrm{C}$ peak at $1909.53 \mathrm{~cm}^{-1}, \mathrm{C}=\mathrm{C}$ peak at $1869.02 \mathrm{~cm}^{-1}, \mathrm{~N}-\mathrm{H}$ peak at $1637.56 \mathrm{~cm}^{-1}, \mathrm{C}-\mathrm{H}$ peak at $1453.16 \mathrm{~cm}^{-1}$, C-C peak at $1412.23 \mathrm{~cm}^{-1}$, C-C peak at $1398.76 \mathrm{~cm}^{-1}, \mathrm{C}-\mathrm{H}$ peak at $1357.17 \mathrm{~cm}^{-1}, \mathrm{~N}-\mathrm{O}$ peak at $1346.78 \mathrm{~cm}^{-1}, \mathrm{C}-\mathrm{N}$ peak at $1220.94 \mathrm{~cm}^{-1}$. Some of the peaks of both $T$. foenum-graecum extract and phospholipid were shown at their physical mixture spectrum indicating no chemical interaction was occurred in this physical mixture.

\section{Differential scanning calorimetry analysis (DSC)}

Differential scanning calorimetry was carried out to ensure formation of complex between $T$. foenum-graecum extract, cholesterol and egg lecithin, to confirm the presence of $T$. foenum-graecum extract in the phytosome.
DSC thermograms of the pure $T$. foenum-graecum extract, cholesterol and egg lecithin, physical mixture of them are shown in Figure 12,13,14. DSC thermogram of Pure $T$. foenum-graecum extract (S I) showed an endothermal peak at $136.40^{\circ} \mathrm{C}$ and its beginning melting point was $131.17^{\circ} \mathrm{C}$, it is attributed to its melting point. Phospholipids and Cholesterol (S II) showed an endothermal peak at $156.40^{\circ} \mathrm{C}$. DSC thermogram of physical mixture of $T$. foenum-graecum extract, cholesterol, phospholipids(S III) showed a endothermal peak at $165.42^{\circ} \mathrm{C}$.

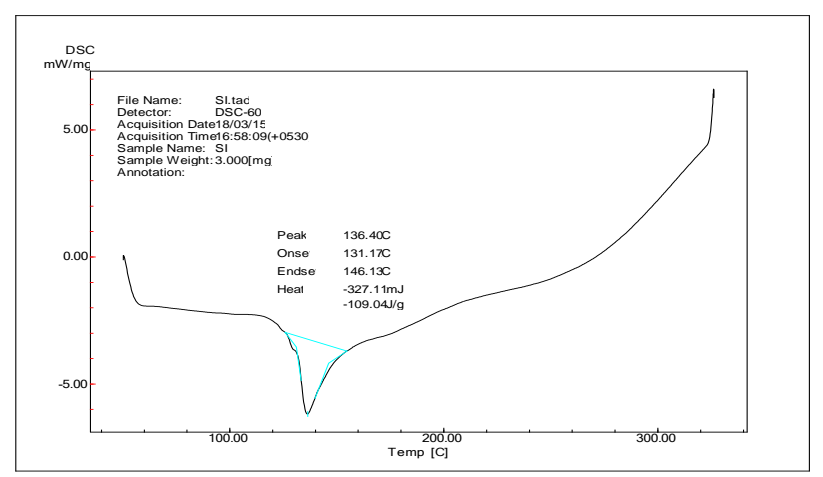

Figure 8: S-I DSC thermogram of extract Trigonella foenumgraecum

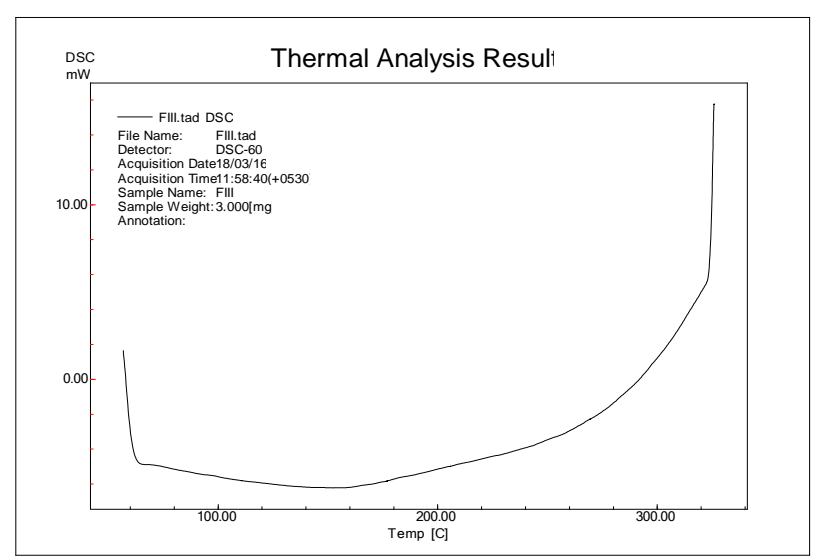

Figure 9: S-II DSC Thermogram of phospholipids and Cholesterol

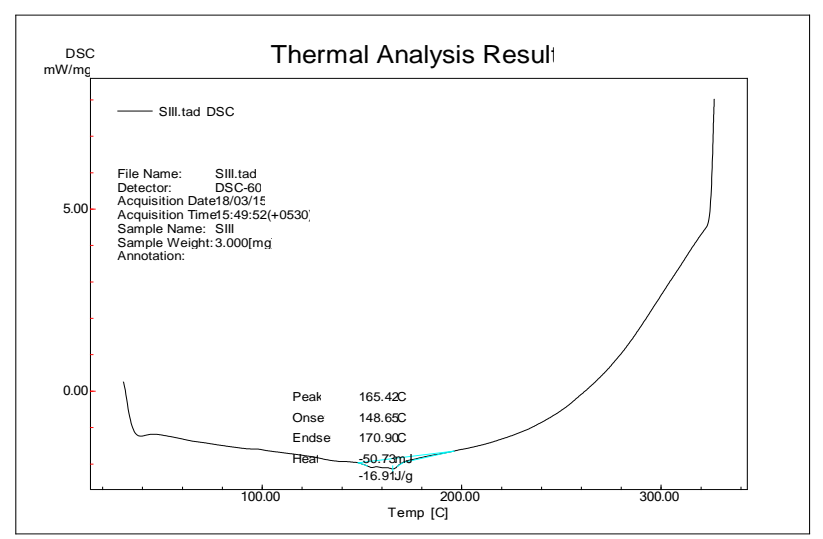

Figure 10: S-III DSC thermogram of physical mixtures of $T$. foenum-graecum extract, phospholipids, cholesterol 
Table 3: Interpretation of FT-IR studies

\begin{tabular}{|c|c|c|c|c|c|}
\hline \multirow[b]{2}{*}{ S. No. } & \multirow[b]{2}{*}{ Functional Group } & \multicolumn{4}{|c|}{ Wave number $\left(\mathrm{cm}^{-1}\right)$} \\
\hline & & Reference & $\begin{array}{l}\text { Trigonella foenum- } \\
\text { graecum Extract }\end{array}$ & Phospholipid & $\begin{array}{l}\text { Euphorbia hirta } \\
\text { nano-phytosome }\end{array}$ \\
\hline 1 & $\begin{array}{l}\text { O-H (stretch) Free hydroxyl, alcohols, } \\
\text { phenols }\end{array}$ & $3640-3610$ & - & - & 3861.49 \\
\hline 2 & $\begin{array}{l}\mathrm{O}-\mathrm{H} \text { (stretch) Free hydroxyl, alcohols, } \\
\text { phenols }\end{array}$ & $3640-3610$ & - & - & 3836.42 \\
\hline 3 & $\mathrm{~N}$-H(stretch) $1^{0}, 2^{0}$ amines, amides & $3400-3250$ & - & - & 3267.41 \\
\hline 4 & $\mathrm{C}-\mathrm{H}$ (stretch) aromatics & $3100-3000$ & - & 3020.53 & - \\
\hline 5 & $\mathrm{C}-\mathrm{H}$ (stretch) alkanes & $3000-2850$ & 2939.52 & 2929.87 & - \\
\hline 6 & $C \equiv N$ (stretch) nitriles & $2260-2210$ & - & - & 2358.94 \\
\hline 7 & $C \equiv N$ (stretch) nitriles & $2260-2210$ & - & - & 2335.80 \\
\hline 8 & $C \equiv N$ (stretch) nitriles & $2260-2210$ & - & - & 2227.78 \\
\hline 9 & $\mathrm{C}=\mathrm{C}($ stretch $)$ alkenes & $1900-2000$ & - & - & 2013.68 \\
\hline 10 & $\mathrm{C}=\mathrm{C}($ stretch $)$ alkanes & $1900-2000$ & - & 1988.61 & 1986.68 \\
\hline 11 & $\mathrm{C}=\mathrm{C}($ stretch $)$ alkenes & $1900-2000$ & - & - & 1909.53 \\
\hline 12 & $\mathrm{C}=\mathrm{C}($ stretch $)$ alkenes & $1900-2000$ & - & - & 1869.02 \\
\hline 13 & $\begin{array}{c}\mathrm{C}=\mathrm{O} \text { (stretch) aldehyde, ketones, } \\
\text { saturated aliphatic }\end{array}$ & $1665-1740$ & 1710.86 & 1734.01 & - \\
\hline 14 & $\mathrm{C}-\mathrm{C}($ stretch) aromatics & $1600-1585$ & 1608.63 & - & 1637.56 \\
\hline 15 & $\mathrm{C}-\mathrm{C}($ stretch) aromatics & $1500-1400$ & 1517.98 & - & 1398.76 \\
\hline 16 & $\mathrm{C}-\mathrm{H}($ Bend) alkanes & $1470-1450$ & - & - & 1453.16 \\
\hline 17 & $\mathrm{C}-\mathrm{C}($ stretch $)$ aromatics & $1500-1400$ & - & - & 1412.23 \\
\hline 18 & $\mathrm{C}-\mathrm{H}$ (rocking) alkanes & $1370-1350$ & 1396.46 & - & 1357.17 \\
\hline 19 & $\begin{array}{l}\mathrm{N}-\mathrm{O} \text { Symmetric (stretch) nitro } \\
\text { compounds }\end{array}$ & $1360-1290$ & - & - & 1346.78 \\
\hline 20 & C-N(stretch) aliphatic amines & $1250-1020$ & 1242.16 & 1215.15 & 1220.94 \\
\hline 21 & C-N(stretch) aliphatic amines & $1250-1020$ & 1066.64 & 1053.13 & - \\
\hline
\end{tabular}

The carbon-hydrogen chain in soya lecithin perhaps happened to be melt, isomerous or the crystal changes. The physical mixture of $T$. foenum-graecum extract, Cholesterol and Phospholipids showed a broad endothermal peak at $165.42^{\circ} \mathrm{C}$. When compare the $T$. foenum-graecum extract $\left(136.40^{\circ} \mathrm{C}\right)$ with Physical mixture $\left(165.42^{\circ} \mathrm{C}\right)$ it showed that there is no wide variation between the peaks and the difference is within $\pm 20^{\circ} \mathrm{C}$. This slight variation in the peaks may be due to the physical interact by Hydrogen bonding between-OH group of $T$. foenum-graecum extract and polar part of phosphatidylcholine. On the other hand, in the T. foenumgraecum extract-cholesterol-phospholipidscomplex, the major endothermic peak was observed at $165.42^{\circ} \mathrm{C}$, which was different from the peaks of the individual components of the complex. Thermogram of Physical mixtures of $T$. foenum-graecum extract, phospholipidsand cholesterol interestingly showed disappearance of the endothermic melting peak of $T$. foenum-graecum extract, indicating that $T$. foenum-graecum was completely embedded inside the matrix of physical mixture which had different thermal properties.

\section{Particle size (PS)}

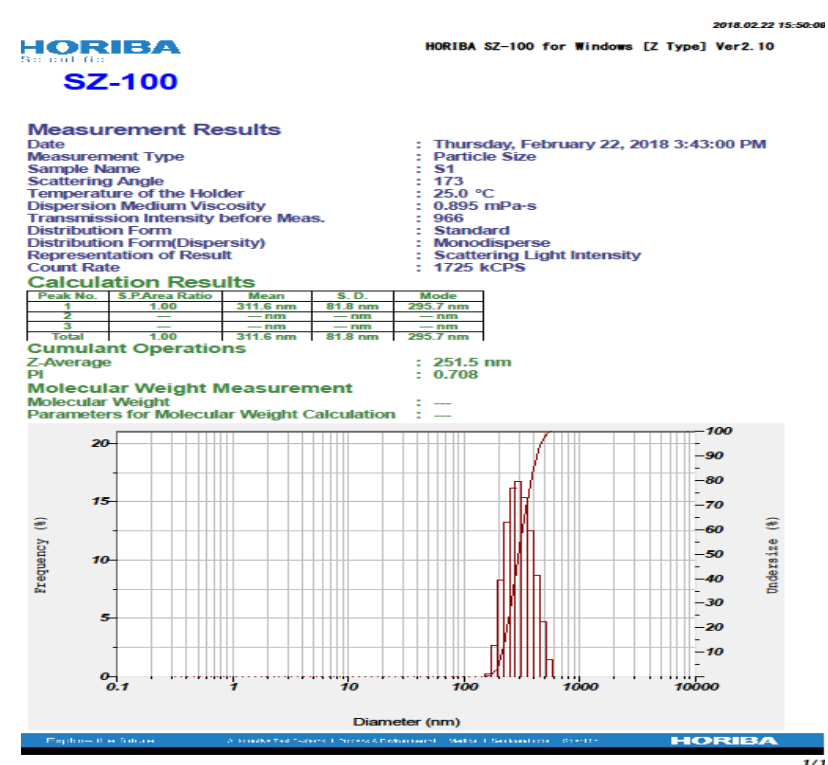

Figure 11: Particle sizes of Trigonella foenum-graecum nano-phytosomes 
Particle size plays an important role in the stability, availability and organoleptic properties of the solution and the particles with smaller size are desirable. Results of particle size analysis indicated that nano-phytosomes prepared with $T$. foenum-graecum extract and $P C$ possess the particle size in the average range of $251 \mathrm{~nm}$. Vesicle size tends to increase with increasing concentration of the complex. When the concentration of particles is too high, physical interaction either collision or electrostatic between vesicles is more pronoun. These interactions alter the movement of the particles and produce vesicles with a larger size. The high lipid composition in the formulation also increases the tendency for the formation of agglomerates, resulting in the bigger size of the vesicles. Polydispersity Index is a measure of the heterogeneity of sizes of molecules or particles in a mixture. T. foenumgraecum nano-phytosome prepared show polydispersity index value of 0.7 (Figure 15). This indicates the uniformity and homogeneity of the size of vesicles in the system. A relative high polydispersity index was observed in $T$. foenum-graecum nano-phytosomes which may be attributed to high phospholipid content.

\section{Zeta Potential (ZP)}
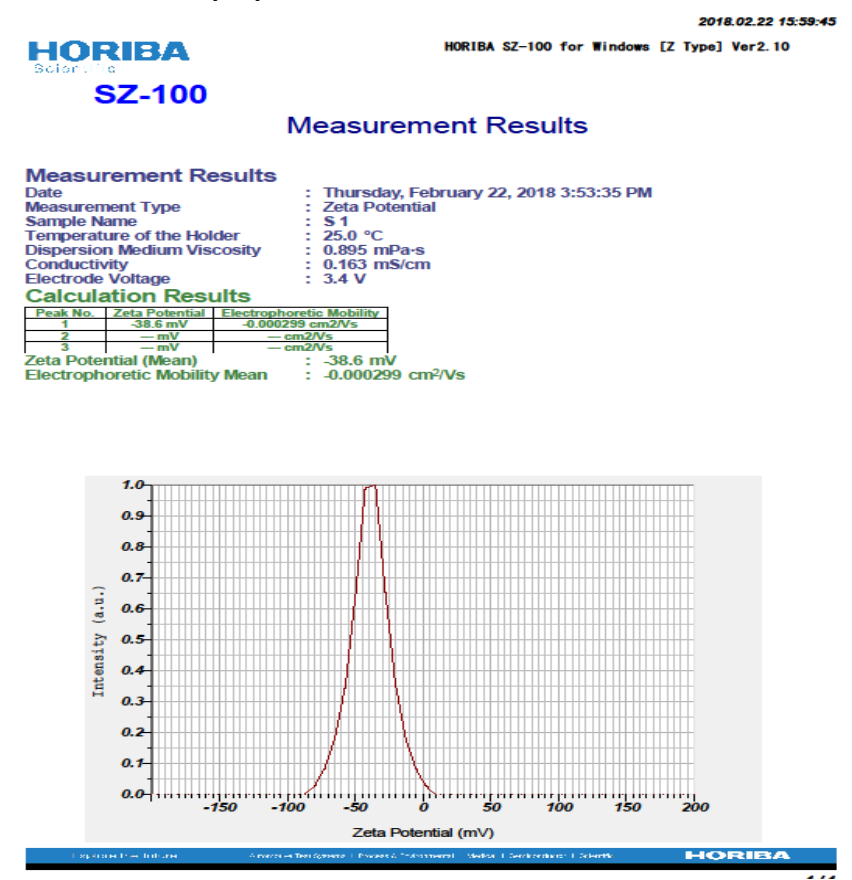

Figure 12: Zeta potential of Trigonella foenum-graecum nano-phytosomes

The Zeta potential is the electric potential in the interface or particle surface and is used to predict the stability of colloidal systems. The magnitude of the Zeta potential indicates the degree of electrostatic repulsion between adjacent, similarly charged particles which affects the stability of colloidal system. Colloids with high absolute Zeta potential values (normally $\pm 30 \mathrm{mV}$ ), regardless of their positivity or negativity, are electrically stabilized and those with low Zeta potential values are not stable and tend to coagulate or flocculate. In general, higher Zeta potential values indicate a higher and longer-term stability of the particles. Several factors such as $\mathrm{pH}$, ionic strength, type and concentration of the used biopolymers are effective on the Zeta potential of the particles. The surface charge analysis results (-38.6 mV) are shown in (Fig 16) and point to the physical stability of T.foenum-graecum nanophytosomes.

\section{Scanning Electron Microscope analysis (SEM)}

Scanning Electron Microscopy give important insight into the solid-state properties, surface morphology of drug and drug complexes. SEM analysis as given in confirms the vesicle size measured by size analyzer i.e., around 100-500 $\mathrm{nm}$. The drug particles are associated with the phospholipids forming complexes with spherical shape, uniform and rigid vesicles.

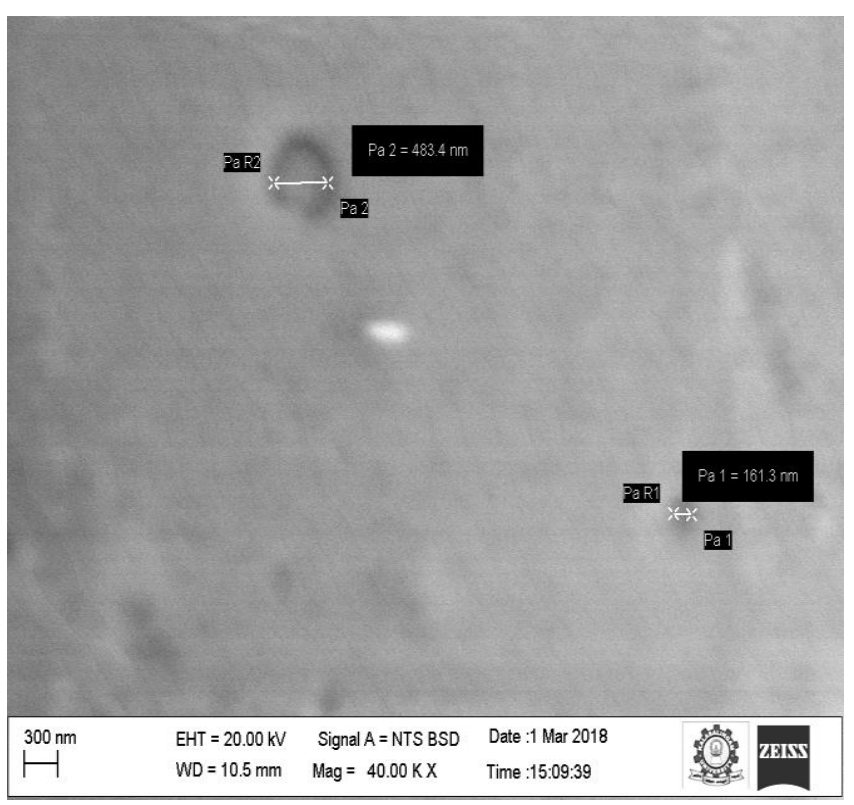

Figure 13: SEM of Nano-phytosome Trigonella foenumgraecum

\section{Transmission Electron Microscope (TEM)}

TEM analysis as presented in confirmed the spherical shape of the vesicle. The aggregation between vesicles was observed in single particle shape, forming irregular large size particles.

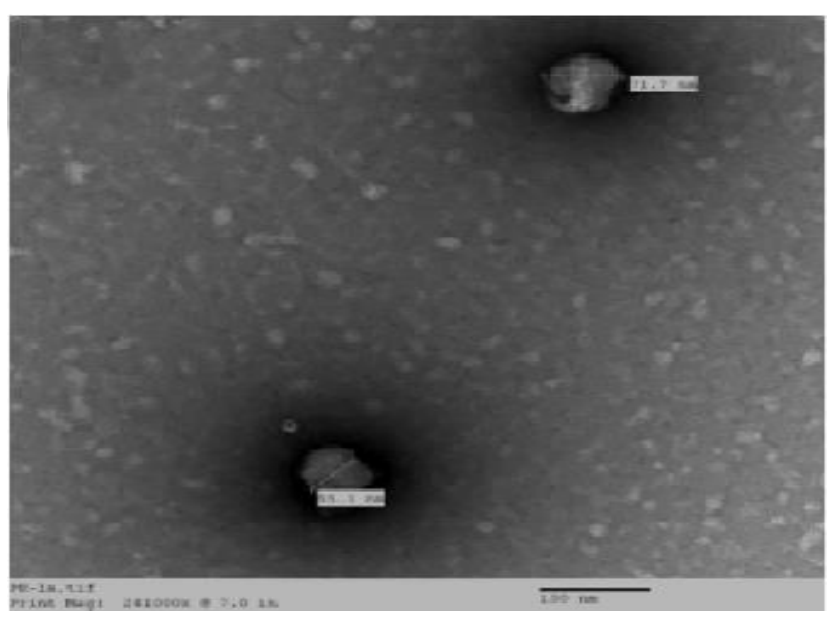

Figure 14: TEM analysis of Trigonella foenumgraecumnano-phytosomes 
TEM pictures depicted that the nanophytosomes are discretely distributed. Nanophytosomes are nearly spherical in shape with smooth surfaces. Tem pictures shows the internal architecture of the nanophytosomes

\section{X-Ray diffaction studies of nanophytosomes}

Presence of single peak at $20^{\circ}$ of 2theta indicates lack of crystalinity of the nanophytosomes and the absence of sharp peaks inferes the drug become amorphous after nanonization process

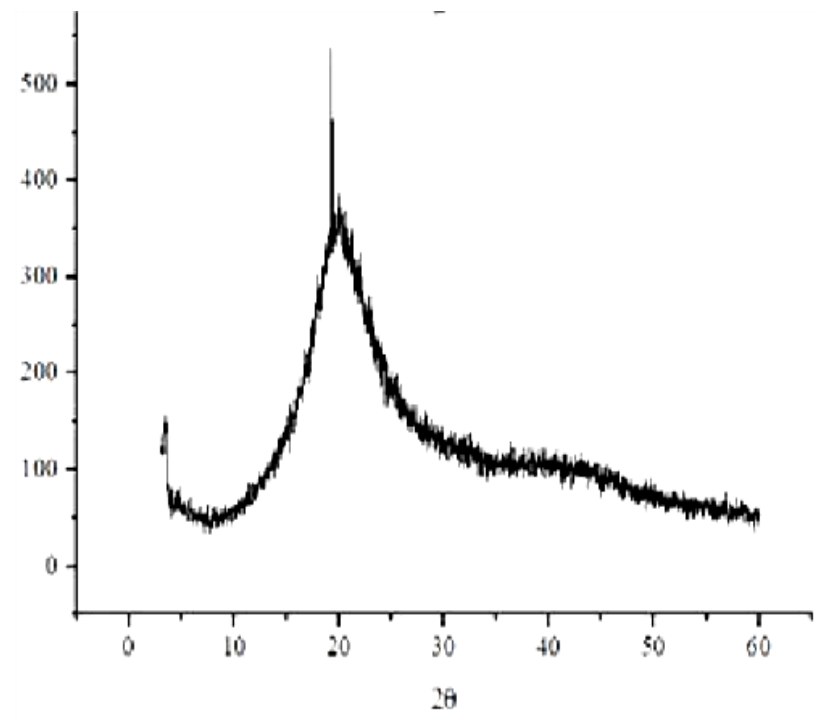

Figure 15: X-rd Analysis of Trigonella foenumgraecumnano-phytosomes

Acknowledgment: I sincerely thank P.Arjunkumar sir for giving me valuable suggestion for this project work.

\section{CONCLUSION}

In the present study, it is concluded that the plant $T$. foenum-graecum contains variety of phytoconstituents. Nanophytosomes of the aqueous extract of the leaves of the plant Trigonella were successfully developed. Phytochemical investigation gave the report of presence of flavonoids and tannins majorly. Preformulation studies confirmed the absence of drug excipient interactions. Characterization studies supported that the formed nanophytosomes are having spherical shapes with smooth surfaces. Zeta size and potential studies revealed that the developed phytosomes are nanometer in size with high macroscopic stability. Hence the preparation of nano phytosomes of Trigonella is an alternative method to increase the therapeutic ability of the plant.

\section{REFERENCES}

1. Fabio Firenzuoli, Luigi Gori. "Herbal medicine today, Clinical and research issues.” 2007; 4: 37-40.

2. Jain N, Gupta BP, Thakur N, Jain R, Banweer J, Jain DK, Jain S. Phytosome: a novel drug delivery system for herbal medicine. Int J Pharm Sci Drug Res. 2010; 2(4): 224-8.

3. Pawar HA, Bhangale BD. Phytosome as a novel biomedicine: a microencapsulated drug delivery system. Journal of Bioanalysis \& Biomedicine. 2015 Jan $1 ; 7(1): 6$.

4. Sharma S, Roy RK. Phytosomes: an emerging technology. Int J Pharm Res Dev. 2010; 2(5): 1-7.

5. Jyoti Verma, Rajesh verma,Vandana Arora Sethi, Rahul singh. Pharmacognostic study of trigonella foenum graecum. Int. J. Res. Dev. Pharm. L. Sci. 2013; Vol. 2, No.6: 708-715

6. Nasroallah Moradi kor, Mohamad Bagher Didarshetaban, Hamid Reza Saeid Pour. Fenugreek (Trigonella foenum-graecum L.) As a Valuable Medicinal Plant. Int J Adv Biol Biom Res. 2013; 1(8): 922-931.

7. Fazli F R Y, Hardman R. The spice fenugreek (Trigonella foenumgraecum). Its commercial varieties of seed as a source of diosgenin. Trop. Sci.1968;10: 66-78.

8. Dr. Renu MishraNishi Yadav,Jyoti Choithani. phytochemical analysis of trigonella foenum graecum and its antibacterial activity against staphylococcus aureus. World J. of Pharmacy and Ph. Sci 2016; Vol 5, Issue 6: 1408-1423

9. Hooresfand Z, Ghanbarzadeh S, Hamishehkar $H$. Preparation and characterization of rutin-loaded nanophytosomes. Pharm Sci. 2015; 21(3): 145-51.

10. Singh RP, Narke R. Preparation and evaluation of phytosome of Lawsone. International Journal of Pharmaceutical Sciences and Research. 2015 Dec 1; 6(12): 5217.

11. Gupta NK, Dixit VK. Bioavailability enhancement of curcumin by complexation with phosphatidyl choline. Journal of pharmaceutical sciences. 2011 May 1; 100(5): 1987-95.

12. Sundaraganapathy, Leena P N. Development and Assessment of Anti-Cancer Activity of Phytosome Using Isolated Compound from Clerodendron Paniculatum Linn Root Extract. Int J Pharma Res Health Sci. 2016; 4 (5): 1399-1402

13. T.Siva Kal, M. Raghavendhra, K.Bharath Reddy, M.ChinnaObulesu, R.Neerajamma. In Vitro Antioxidant Activity of Methanolic Extract of Trigonella foenum-graecum . ljppr.Human, 2016; Vol. 7 (1): 476-510. 
14. Pranjal Ray, Bhupen Kalita. Formulation and evaluation pf Phospholipid complex of Green Tea Polyphenol. Int. J. Res. Dev. Pharm. L. Sci. r 2017; 6(6): 2813-2819.

15. Darshana Patil, Avinash Patil, Aqsa Ansari. Standardization and quality control parameters of aerial parts (Leaves and Stem) of Trigonella foenum- graecum L.-An important medicinal plant. J of Che and Ph. Res, 2015; 7(3): 163-170

16. Vasanthi R, Greeshma G, Sowmya Sri K, Akhila K, Saikumar M, Shaistha. A Comparative Study on Phytochemical and In Vitro Antioxidant Activity of Trigonella foenum graecum L. Der Pharma Chemica, 2017; 9(16): 22-24.

Source of Support: The author(s) received no financial support for the research, authorship, and/or publication of this article.

Conflict of Interest: The author(s) declared no potential conflicts of interest with respect to the research, authorship, and/or publication of this article.

For any question relates to this article, please reach us at: editor@globalresearchonline.net New manuscripts for publication can be submitted at: submit@globalresearchonline.net and submit_ijpsrr@rediffmail.com 